\title{
Conjunctival bacterial flora and antibiotic resistance pattern in patients undergoing cataract surgery
}

\author{
Flora bacteriana conjuntival e padrãode resistência a antibióticos em pacientes \\ submetidosà cirurgia decatarata
}

\author{
Tiago Eugênio Faria e Arantes ${ }^{1}$ \\ Ronald Fonseca Cavalcanti ${ }^{2}$ \\ Maria de Fátima Alves Diniz ${ }^{3}$ \\ Maiara Santos Severo ${ }^{4}$ \\ João Lins Neto ${ }^{5}$ \\ Célia Maria Machado Barbosa de Castro ${ }^{6}$
}

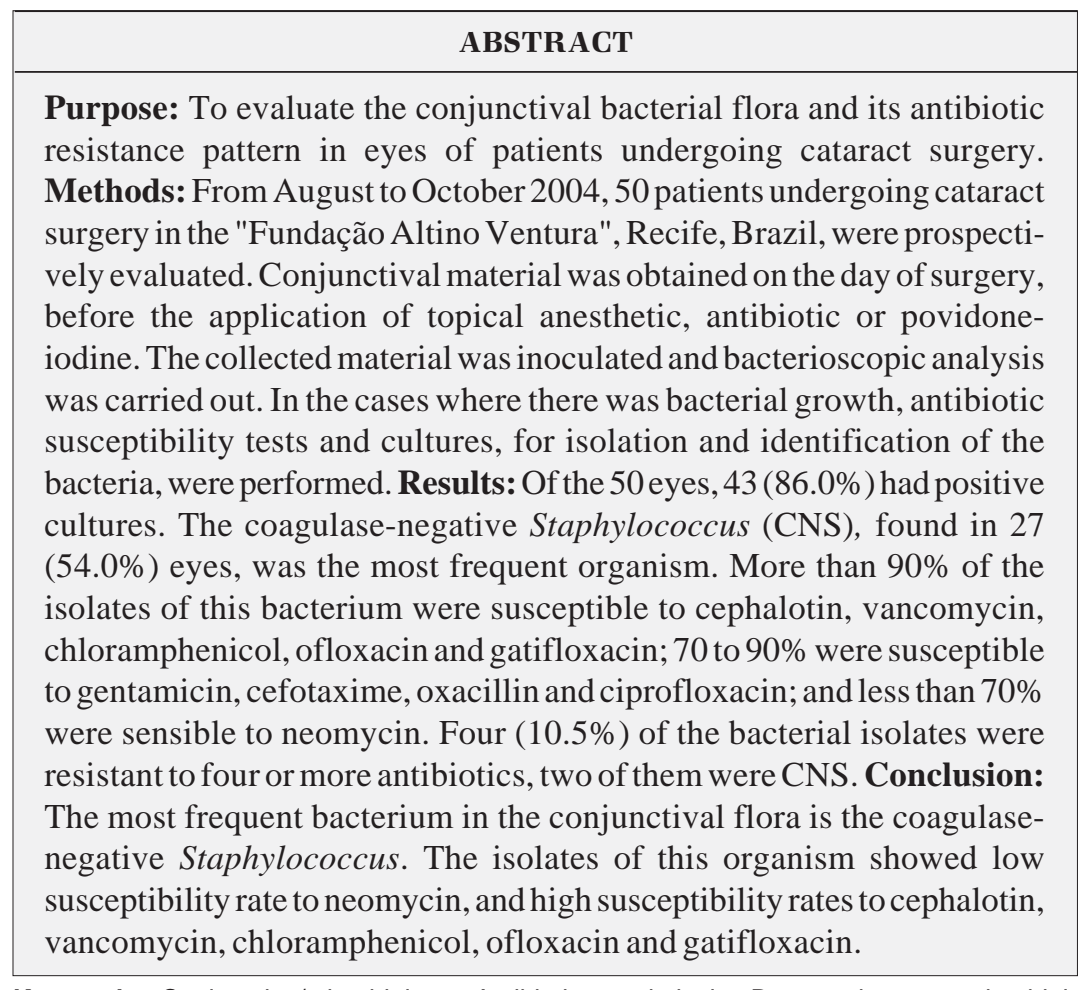

Keywords: Conjunctiva/microbiology; Antibiotic prophylaxis; Drug resistance, microbial; Cataract extraction; Endophthalmitis; Staphylococcus/isolation \& purification

\section{INTRODUCTION}

Cataract surgery is one of the most performed operations in the world. In the Unites States of America approximately 1.5 million procedures are performed annually ${ }^{(1)}$. One of the most feared complications of this surgery is endophthalmitis that, although infrequent, leads to high visual morbidity even with appropriate treatment. For this reason, ophthalmologists adopt several measures for its prophylaxis ${ }^{(2)}$.

Possible sources of postoperative ocular infection are the ocular tear film, ocular adnexa, irrigation solutions, surgical instruments, respiratory and skin flora of the surgeon and assistants and operating room air ${ }^{(2)}$. Bacteria are the most common group of causative agents of endophthalmitis and gram-positive pathogens are responsible for 60 to $80 \%$ of acute infections ${ }^{(2)}$. Previous studies have shown that most bacteria responsible for postoperative ocular infection are part of the normal microbiota of the 
conjunctiva and eyelids of the patient ${ }^{(3-4)}$. The culture is positive in 50 to $85 \%$ of the vitreous aspirates and the coagulasenegative Staphylococcus (Staphylococcus epidermidis) is the most frequently isolated pathogen, followed by S. aureus and Streptococcus spp, gram-negative organisms are responsible for $20 \%$ of the infections ${ }^{(5)}$. Studies have shown that the superficial flora penetrates the anterior chamber during cataract surgery but that does not necessarily lead to infection, suggesting that the anterior chamber could eliminate a small inoculum of bacteria without developing endophthalmitis ${ }^{(6-7)}$.

Once superficial flora enters the eye during the cataract surgery, several prophylactic measures are applied to suppress or limit the growth of these microorganisms, which could lead to endophthalmitis. Thus, the use of topical antibiotics before and after cataract surgery is justified as they are efficient in reducing and, sometimes, temporarily eliminating the conjunctival microbiota ${ }^{(2,8)}$. However, not many studies evaluate the effect of topical antibiotics on endophthalmitis incidence, so the use of these drugs before surgery is considered as probably relevant for infection prophylaxis, but not definitely related to clinical outcome ${ }^{(2)}$.

The choice for the prophylactic topical antibiotic is influenced by factors as spectrum of bacteria covered, the rapidity with which the antibiotic eliminates bacteria from the conjunctival surface, the duration of action, the penetration and toxicity of the antibiotic, the antibiotic susceptibility pattern and the $\operatorname{cost}^{(9-11)}$. Fluoroquinolones are commonly used agents for endophthalmitis prophylaxis, although there is the possibility that the resistance of the ocular bacterial flora to these antibiotics is increasing ${ }^{(9-12)}$.

The purpose of this study was to evaluate the conjunctival bacterial flora and its antibiotic susceptibility pattern in eyes of patients undergoing cataract surgery.

\section{METHODS}

From August to October 2004, 50 patients undergoing cataract surgery in the "Fundação Altino Ventura", Recife, Pernambuco, Brazil, were prospectively evaluated. All patients underwent ophthalmologic evaluation and patients with signs of ocular infection were excluded.

Conjunctival material was obtained on the day of surgery before the application of topical anesthetic, antibiotic or povidone-iodine. The inferior conjunctival fornix was swabbed, without touching eyelid or lashes, the swab was then stored in
Stuart transport medium. The collected material was inoculated and, when there was bacterial growth, cultures for isolation and identification of the bacteria were made and antibiotic susceptibility tests were carried out. The microbiological investigation followed these steps:

1. Microscopic examination: once collected the swab was rolled across a microscope glass slide, then was rapidly heat-fixed and colored by the Gram stain method.

2. Culture: two plates (blood agar and agar Levine) were used for the bacterial culture and one plate (agar Sabouraud) for the culture of fungus. The material collected by the swab was rolled in a Petri plate with solid culture medium and spread with a platinum wire in lines, covering all surface of the plate. This procedure allowed the isolated growth of the colonies. Later, the plates were incubated at $36 \pm 1^{\circ} \mathrm{C}$ for 24 to 48 hours and if the culture was positive antibiotic susceptibility tests were carried out.

3. Antibiotic susceptibility tests: the sensitivity of the isolated microorganisms was determined by the discdiffusion method. The reading was made measuring the inhibition halo surrounding the disc.

Statistical analysis was performed using chi-square test, Fisher exact test and Fisher-Freeman-Halton exact test, $\mathrm{p}<0.05$ was used for rejecting the null hypothesis.

The study was initiated after the approval by the "Fundação Altino Ventura" Ethics Committee and patients included in this study after their consent was obtained.

\section{RESULTS}

Of the 50 patients participating in this study, $56.0 \%$ were females and $44.0 \%$ males, the mean age was $67.6 \pm 11.8$ years. The cultures were positive in $86.0 \%$ of the eyes.

Forty $(88.9 \%)$ of the microorganisms isolated were grampositive and five $(11.1 \%)$ were gram-negative. The most frequently isolated bacterium was the coagulase-negative Staphylococcus (CNS), found in 27 eyes (54.0\%). Bacillus sp. was isolated from six eyes (12.0\%), S. aureus from four eyes (8.0\%), Citrobacter freundii from three eyes (6.0\%), and S. saprophyticus, Corynebacterium sp., Proteus penneri, Enterococcus sp. and Morganelia morganii from one eye (2.0\%) each. From two eyes, more than one type of bacterium was isolated.

The antibiotic susceptibility pattern of the isolated colonies is presented in Table 1. The isolates of these organisms, grouped together, showed low susceptibility rate to neomy-

\begin{tabular}{|c|c|c|c|c|c|c|c|c|c|c|}
\hline & Neomycin & Gentamicin & Cephalotin & Cefotaxime & Oxacillin & Vancomycin & Chloramphenicol & Ciprofloxacin & Ofloxacin & Gatifloxacin \\
\hline $\mathrm{N}$ & 38 & 38 & 38 & 38 & 38 & 38 & 38 & 38 & 38 & 38 \\
\hline S & $47.4 \%$ & $79.0 \%$ & $94.7 \%$ & $89.4 \%$ & $76.3 \%$ & $89.5 \%$ & $92.1 \%$ & $89.5 \%$ & $97.4 \%$ & $100.0 \%$ \\
\hline I & $34.2 \%$ & $2.6 \%$ & $0.0 \%$ & $5.3 \%$ & $0.0 \%$ & $0.0 \%$ & $0.0 \%$ & $2.6 \%$ & $0.0 \%$ & $0.0 \%$ \\
\hline $\mathrm{R}$ & $18.4 \%$ & $18.4 \%$ & $5.3 \%$ & $5.3 \%$ & $23.7 \%$ & $10.5 \%$ & $7.9 \%$ & $7.9 \%$ & $2.6 \%$ & $0.0 \%$ \\
\hline
\end{tabular}


cin, and high susceptibility rate to cephalotin, chloramphenicol, ofloxacin and gatifloxacin. The isolates of CNS showed low susceptibility rate to neomycin, and high susceptibility rates to cephalotin, vancomycin, chloramphenicol, ofloxacin and gatifloxacin (Table 2). Tables 3 and 4 show the patterns of other isolated pathogens. It was not possible to perform the antibiogram for the anaerobic organisms.

There was no statistical difference in the frequencies of susceptibility of CNS between the fluoroquinolones. Both, ofloxacin and ciprofloxacin had similar susceptibility patterns compared to gatifloxacin ( $\mathrm{p}=1.000$ and $\mathrm{p}=0.236$, respectively). The CNS was less sensitive to neomycin than to gentamicin $(\mathrm{p}=0.003)$, suggesting a greater resistance of this microorganism to neomycin.

Among the bacterial colonies for which antibiotic susceptibility tests were carried out, $10.5 \%$ showed resistance to several antibiotics (four or more), two of these isolates were CNS, both of them were resistant to oxacillin and susceptible to vancomycin and gatifloxacin. Organisms resistant to vancomycin were found in four eyes and all of them were gram-negative (Citrobacter freundii in three and Morganella morganii in one case).

Microscopic examination was performed in all cases, in $10.0 \%$ of them no organisms were found in the glass slide, $74.0 \%$ showed gram-positive cocci, $64.0 \%$ gram-positive bacilli, $8.0 \%$ gram-negative bacilli and in $4.0 \%$ of the cases a fungus was found (Candida sp.). Some glass slides showed more than one type of organism.

\section{DISCUSSION}

The resistance rates to antibiotics are growing with the dissemination and prolonged use of antimicrobial agents. Based on this, the characterization of bacterial ocular flora and its susceptibility pattern is highly justified, as it gives the surgeon a powerful tool to help in the choice of the most appropriate antibiotic to be used in the prophylaxis of his ocular surgeries ${ }^{(9)}$.

It is known that the use of prophylactic antibiotics in cataract surgery reduces the number of organisms in the conjunctiva and eyelids ${ }^{(2-3)}$, other desirable characteristics are good bioavailability, broad-spectrum coverage and favorable susceptibility patterns ${ }^{(9-11)}$.

In this study, the most frequently found organism was the CNS, as shown in other studies ${ }^{(8-9,13-14)}$, this organism is related to approximately $70 \%$ of the cases of postsurgical endophthalmitis ${ }^{(15)}$.

There was a low susceptibility rate to neomycin, only $47.4 \%$ of the isolates were sensitive to this antibiotic. This may be due to indiscriminate and prolonged use of this agent and the common practice of self-medication found in Brazil. Fluoroquinolones are among the antibiotics commonly used in cataract surgery prophylaxis. We found a reduction in the susceptibility rates to the older quinolones ( 89.5 and $97.4 \%$ of the isolates are sensitive to ciprofloxacin and ofloxacin, respectively), compared to the latest generation quinolone gatifloxacin (100.0\% of susceptibility).

\begin{tabular}{|c|c|c|c|c|c|c|c|c|c|c|}
\hline & Neomycin & Gentamicin & Cephalotin & Cefotaxime & Oxacillin & Vancomycin & Chloramphenicol & Ciprofloxacin & Ofloxacin & Gatifloxacin \\
\hline $\mathrm{N}$ & 27 & 27 & 27 & 27 & 27 & 27 & 27 & 27 & 27 & 27 \\
\hline$S$ & $55.6 \%$ & $85.2 \%$ & $100.0 \%$ & $85.2 \%$ & $85.2 \%$ & $100.0 \%$ & $92.6 \%$ & $88.9 \%$ & $96.3 \%$ & $100.0 \%$ \\
\hline I & $33.3 \%$ & $0.0 \%$ & $0.0 \%$ & $7.4 \%$ & $0.0 \%$ & $0.0 \%$ & $0.0 \%$ & $3.7 \%$ & $0.0 \%$ & $0.0 \%$ \\
\hline $\mathrm{R}$ & $11.1 \%$ & $14.8 \%$ & $0.0 \%$ & $7.4 \%$ & $14.8 \%$ & $0.0 \%$ & $7.4 \%$ & $7.4 \%$ & $3.7 \%$ & $0.0 \%$ \\
\hline
\end{tabular}

\begin{tabular}{|c|c|c|c|c|c|c|c|c|c|c|}
\hline & Neomycin & Gentamicin & Cephalotin & Cefotaxime & Oxacillin & Vancomycin & Chloramphenicol & Ciprofloxacin & Ofloxacin & Gatifloxacin \\
\hline $\mathrm{N}$ & 4 & 4 & 4 & 4 & 4 & 4 & 4 & 4 & 4 & 4 \\
\hline$S$ & $50.0 \%$ & $100.0 \%$ & $100.0 \%$ & $100.0 \%$ & $100.0 \%$ & $100.0 \%$ & $100.0 \%$ & $100.0 \%$ & $100.0 \%$ & $100.0 \%$ \\
\hline I & $25.0 \%$ & $0.0 \%$ & $0.0 \%$ & $0.0 \%$ & $0.0 \%$ & $0.0 \%$ & $0.0 \%$ & $0.0 \%$ & $0.0 \%$ & $0.0 \%$ \\
\hline $\mathrm{R}$ & $25.0 \%$ & $0.0 \%$ & $0.0 \%$ & $0.0 \%$ & $0.0 \%$ & $0.0 \%$ & $0.0 \%$ & $0.0 \%$ & $0.0 \%$ & $0.0 \%$ \\
\hline
\end{tabular}

\begin{tabular}{|c|c|c|c|c|c|c|c|c|c|c|}
\hline & Neomycin & Gentamicin & Cephalotin & Cefotaxime & Oxacillin & Vancomycin & Chloramphenicol & Ciprofloxacin & Ofloxacin & Gatifloxacin \\
\hline $\mathrm{N}$ & 3 & 3 & 3 & 3 & 3 & 3 & 3 & 3 & 3 & 3 \\
\hline $\mathrm{S}$ & $0.0 \%$ & $66.7 \%$ & $66.7 \%$ & $100.0 \%$ & $0.0 \%$ & $0.0 \%$ & $100.0 \%$ & $100.0 \%$ & $100.0 \%$ & $100.0 \%$ \\
\hline I & $100.0 \%$ & $0.0 \%$ & $0.0 \%$ & $0.0 \%$ & $0.0 \%$ & $0.0 \%$ & $0.0 \%$ & $0.0 \%$ & $0.0 \%$ & $0.0 \%$ \\
\hline $\mathrm{R}$ & $0.0 \%$ & $33.3 \%$ & $33.3 \%$ & $0.0 \%$ & $100.0 \%$ & $100.0 \%$ & $0.0 \%$ & $0.0 \%$ & $0.0 \%$ & $0.0 \%$ \\
\hline
\end{tabular}


The CNS was more susceptible to oxacillin than it was described in a previous study ${ }^{(9)}$, suggesting low rate of methicillin resistance in the institution where this study was carried out.

The number of CNS isolates resistant to 4 or more antibiotics $(7.4 \%)$ was lower than the $39 \%$ described by Ta et al. ${ }^{(9)}$, and similar to the one found by Pinna et al., $(9.0 \%)^{(16)}$. Our results imply low rates of ocular colonization with multiresistant bacteria and demographic differences in the resistance pattern of the ocular bacterial flora.

In the microscopic examinations, as in the cultures, a predominance of gram-positive bacteria was found.

Another point to be considered is that our tests of antibiotic sensitivity were performed in vitro and might not reflect the real efficiency of these antibiotics in vivo. In addition, the disc-diffusion sensitivity test technique is based on the serum concentration of the antibiotics that might be different from the concentration in the conjunctiva with the topical use of eye drops ${ }^{(9)}$. This suggests that our study can be used by the ophthalmologists as an orientation tool when choosing a prophylactic antibiotic to be used in their surgeries but our results should be confirmed by in vivo tests.

\section{CONCLUSION}

This study showed that the bacterium most frequently found in the conjunctival flora of the patients undergoing cataract surgery was the CNS. Isolates of this bacterium had low susceptibility rates to neomycin and high susceptibility to cephalothin, vancomycin, chloramphenicol, ofloxacin and gatifloxacin.

Nowadays, with the considerable increase of bacterial resistance to antibiotics, the understanding of the sensitivity of the conjunctival bacterial flora to antibiotics is of fundamental importance. Additionally, these studies can guide the ophthalmologists when choosing a prophylactic antibiotic to be used in their surgeries.

\section{RESUMO}

Objetivo: Avaliar a flora bacteriana conjuntival e seu padrão de resistência a antibióticos em olhos de pacientes a serem submetidos a cirurgias de catarata. Métodos: Foram avaliados, prospectivamente, os olhos de 50 pacientes a serem submetidos a facectomias na Fundação Altino Ventura, Recife (PE), durante o período de agosto a outubro de 2004. Foi coletado material para cultura da conjuntiva no dia da cirurgia, antes da aplicação de anestésicos, antibióticos ou iodo povidona tópicos. A partir do material coletado foram realizados bacterioscopias e semeio. Em caso de crescimento bacteriano, foram realizadas culturas para isolamento e identificação das bactérias e preparação de antibiogramas. Resultados: Entre os 50 olhos estudados, sete $(14,0 \%)$ apresentaram culturas negativas e $43(86,0 \%)$ culturas positivas. A bactéria mais freqüentemente isolada foi o Staphylococcus coagulase-negativo, en- contrada em 27 olhos (54,0\%). Entre os isolados desta bactéria, mais de $90 \%$ foram sensíveis a cefalotina, vancomicina, cloranfenicol, ofloxacino e gatifloxacino; 70 a 90\% destes microrganismos foram sensíveis a gentamicina, cefotaxima, oxacilina e ciprofloxacino; menos que $70 \%$ deles foram sensíveis à neomicina. Encontrou-se quatro $(10,5 \%)$ isolados de bactérias resistentes a quatro ou mais antibióticos, sendo que dois deles foram de Staphylococcus coagulase-negativo (7,4\% dos isolados desta bactéria). Conclusão: A bactéria mais freqüentemente encontrada na conjuntiva foi o Staphylococcus coagulase-negativo, sendo que estes isolados mostraram alta resistência aos aminoglicosídeos, principalmente à neomicina, com alta suscetibilidade à cefalotina, vancomicina, cloranfenicol, ofloxacino e gatifloxacino.

Descritores: Conjuntiva/microbiologia; Antibioticoprofilaxia; Resistência microbiana a drogas; Extração de catarata; Endoftalmite; Staphylococcus/isolamento \& purificação

\section{REFERENCES}

1. Javitt JC, Kendix M, Tielsch JM, Steinwachs DM, Schein OD, Kolb MM, et al. Geographic variation in utilisation of cataract surgery. Med Care. 1995;33(1): 90-105.

2. Ciulla TA, Starr MB, Masket S. Bacterial endophthalmitis prophylaxis for cataract surgery: an evidence-based update. Ophthalmology. 2002;109(1):13-24.

3. Kanellopoulos AJ, Dreyer EB. Postoperative infection following current cataract extraction surgery. Int Ophthalmol Clin. 1996;36(3):97-107.

4. Sunaric-Megevand G, Pournaras CJ. Current approach to postoperative endophthalmitis. Br J Ophthalmol. 1997;81(11):1006-15.

5. Speaker MG, Milch FA, Shah MK, Eisner W, Kreiswirth BN. Role of external bacterial flora in the pathogenesis of acute postoperative endophthalmitis. Ophthalmology. 1991;98(5):639-49.

6. Dickey JB, Thompson KD, Jay WM. Anterior chamber aspirate cultures after uncomplicated cataract surgery. Am J Ophthalmol. 1991;112(3):278-82.

7. Samad A, Solomon LD, Miller MA, Mendelson J. Anterior chamber contamination after uncomplicated phacoemulsification and intraocular lens implantation. Am J Ophthalmol. 1995;120(2):143-50.

8. Höfling-Lima AL, Farah ME, Montenegro L, Alvarenga LS, Chalita MRC, You MCZ. Alterações da microbiota conjuntival e palpebral após uso tópico de lomefloxacina e tobramicina na cirurgia de catarata e cirurgia refrativa. Arq Bras Oftalmol. 2002;65(1):21-9.

9. Ta CN, Chang RT, Singh K, Egbert PR, Shriver EM, Blumenkranz MS, et al. Antibiotic resistance patterns of ocular bacterial flora. Ophthalmology. 2003; 110(10):1946-51.

10. Ta CN, Egbert PR, Singh K, Shriver EM, Blumenkranz MS, Mino De Kaspar $\mathrm{H}$. Prospective randomized comparison of 3-day versus 1-hour preoperative ofloxacin prophylaxis for cataract surgery. Ophthalmology. 2002;109(11):2036-40.

11. Snyder-Perlmutter LS, Katz HR, Melia M. Effect of topical ciprofloxacin $0.3 \%$ and ofloxacin $0.3 \%$ on the reduction of bacterial flora on the human conjunctiva. J Cataract Refract Surg. 2000;26(11):1620-5.

12. Graves A, Henry M, O’Brien TP, Hwang DG, Van Burskirk A, Trousdale MD. In vitro susceptibilities of bacterial ocular isolates to fluoroquinolones. Cornea. 2001;20(3):301-5.

13. Garcia-Sáenz MC, Peral Ortiz de la Torre MJ, De Castro Liébana M, Jiménez Martínez E, García Sánchez JE, Fresnadillo Sánchez MJ. Flora conjuntival según edades. Arch Soc Esp Oftalmol. 1999;74(7):379-84.

14. Locatelli CI, Kwitko S, Simonetti AB. Conjunctival endogenous microbiota in patients submitted to cataract surgery. Braz J Microbiol. 2003;34(3):203-8.

15. Han DP, Wisniewski SR, Wilson LA, Barza M, Vine AK, Doft BH, et al. Spectrum and susceptibilities of microbiologic isolates in the Endophthalmitis Vitrectomy Study. Am J Ophthalmol. 1996;122(1):1-17.

16. Pinna A, Zanetti S, Sotgiu M, Sechi LA, Fadda G, Carta F. Identification and antibiotic susceptibility of coagulase negative staphylococci isolated in corneal/ external infections. Br J Ophthalmol. 1999;83(7):771-3. Comment in: Br J Ophthalmol. 2000;84(2):229. 